\begin{tabular}{|c|c|c|}
\hline (150 & $\begin{array}{c}\text { Bulletin of Pharmaceutical Sciences } \\
\text { Assiut University }\end{array}$ & 2 \\
\hline 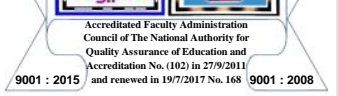 & $\begin{array}{l}\text { Website: http://bpsa.journals.ekb.eg/ } \\
\text { e-mail: bullpharm@aun.edu.eg }\end{array}$ & $\begin{array}{l}\text { BULLL. PHARM. SCI. } \\
\text { Assiut Univ. }\end{array}$ \\
\hline
\end{tabular}

\title{
EFFECT OF STEAMING ON THE ANTIOXIDANTS OF BRASSICA OLERACEA SPROUT, A COOL-WEATHER CROP COLLECTED FROM NILGIRIS
}

\author{
Ramu Govindan
}

\author{
Department of Pharmacognosy, JSS College of Pharmacy, JSS Academy of Higher Education \\ \& Research, Ooty, Nilgiris, Tamilnadu, India
}

\begin{abstract}
Green leafy vegetables are high in minerals and antioxidant vitamins, as well as other antioxidant components like polyphenols and carotenoids, which can scavenge free radicals. In the present study, the effect of steaming was studied on the antioxidant activity, the content of vitamin $C$, calcium, and oxalate antinutrient of Brassica oleracea sprout (BOS) which is commonly known as Broccoli. The physicochemical and preliminary phytochemical screening was carried out according to standard methods. The antioxidant potential was assessed by using a 2,2 diphenyl -1-picryl hydrazine (DPPH) scavenging assay. Calcium, oxalate, and vitamin $C$ were determined by simple titration methods. BOS steam heating did not affect vitamin $C$ levels. BOS didn't show any considerable loss in vitamin $C$ and calcium, but oxalate was reduced to a great extent as a result of steaming. The steaming method seemed to preserve better the vitamin $C$ and calcium with a very less decrease after 10 and 20 min. of steaming. The fresh weight after steaming, in comparison to the raw one, showed a decrease due to a water loss of the vegetable tissue. The steaming method showed better results in preserving the nutrients of BOS and the desired pharmacological property can be expected.
\end{abstract}

\section{INTRODUCTION}

Broccoli is an edible plant that belongs to the italic cultivar group of the Brassica oleracea species ${ }^{1}$. It is a cruciferous vegetable that belongs to the Brassicaceae family. It is thought to have originated in Italy around 2000 years ago. Broccolo is the diminutive form of broccoli, which means "small nail" or "sprout" in Italian. It signifies the "flowering crest of a cabbage." Broccoli has a huge green blossom head that looks like a tree and branches out from a sturdy eating stalk. Broccoli, which resembles cauliflower, has long been regarded as a particularly valuable food among Italians. Chou broccoli, common broccoli, calabrese, and cruciferous vegetable are some of its common names. Broccoli comes in three varieties. Calabrese broccoli, sometimes known as "broccoli," is the most well-known. The stems are thick and the heads are green. Sprouting broccoli is made up of a lot of heads with a lot of stalks. Purple cauliflower is shaped like a head and has small flower buds. Broccoli is a cool-weather crop that thrives at temperatures between 18 and 23 degrees.

Natural antioxidants and physiologically active components can be found in abundance in vegetables ${ }^{2}$. They aid in the delivery of specific nutrients that are lacking in other diets. According to epidemiological research, a diet high in cruciferous vegetables like broccoli, kale, kai Choi, cabbage, Brussels sprouts, and watercress can lower cancer risk. Glucoraphanin, glucoiberin, sulforaphane, carotenoids, vitamins, and myrosinase are all chemical components of broccoli ${ }^{3 \& 4}$. Broccoli has a lot of vitamin $\mathrm{C}$ and fiber. It includes a variety of elements, including diindolylmethane (DIM) and a trace quantity of selenium, both of which have anticancer potential. Broccoli includes the anticancer chemical glucoraphanin, which can be converted to sulforaphane $e^{5-8}$. 
Generally, leafy vegetables contain a high concentration of nutrients and low to high levels of antinutrientients as well. Nutrients have been linked to improvements in human health. Antinutrients are very less common among today's men which can result in nausea, bloating, headaches, rashes, and nutritional deficiencies 9 . Toxic amino acids, chlorogenic acid, lectins, phytic acid, oxalates, protease, and amylase inhibitors are among the few antinutrients present in plant sources ${ }^{10}$. Antinutrient levels can be reduced to acceptable levels as a result of processing. Antinutrients could be reduced to some degree by the use of soaking, cooking, boiling, and blanching techniques. Soaking reduces the amount of phytate and oxalate in foods. But these cooking methods will easily remove the nutrients to a certain extent. So a suitable method has to be followed to retain the nutrients in the leafy vegetables. Broccoli (Brassica oleracea var. Italica) is a vegetable with excellent nutritional value, containing high quantities of vitamins, antioxidants, and anticarcinogenic substances ${ }^{11 \& 12}$.

The majority of vegetables are prepared before being eaten. Vegetables are typically prepared at home for convenience and taste rather than for nutrition and health-promoting components retention ${ }^{13}$. Cooking is known to change the chemical composition of vegetables, changing their bioavailability and content of chemopreventive chemicals. The contents of nutritional and health-promoting substances such as vitamin $\mathrm{C}$ and vitamin $\mathrm{E}$ have been proven to be affected by cooking methods ${ }^{14-17}$.

In this view, our present study aims to evaluate the impact of steam cooking on the vitamin $\mathrm{C}$ content, calcium, oxalate, and antioxidant activity of the traditional vegetable Broccoli (Brassica oleracea) collected in the Nilgiris district which has enormous therapeutic properties.

\section{MATERIALS AND METHODS}

\section{Plant materials}

Brassica oleracea sprout (BOS), a coolweather crop was procured from the local region of the Nilgiris district, Tamilnadu, India.

\section{Processing treatments}

The sample (300 g) was divided into three portions (100 g each), one of which was kept as a control (unsteamed, stored at $4^{\circ} \mathrm{C}$ in the refrigerator until use within $24 \mathrm{hrs}$.), and the other two were steamed for 10 minutes and 20 minutes on a perforated tray in a stainless steel steamer covered over boiling water, and then quickly cooled on ice (Fig. 1a \& 1b).

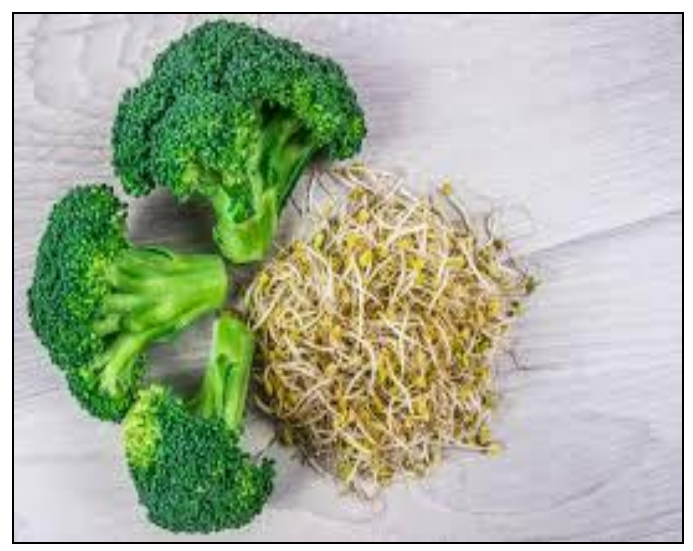

Fig. 1a : Broccoli crude drug

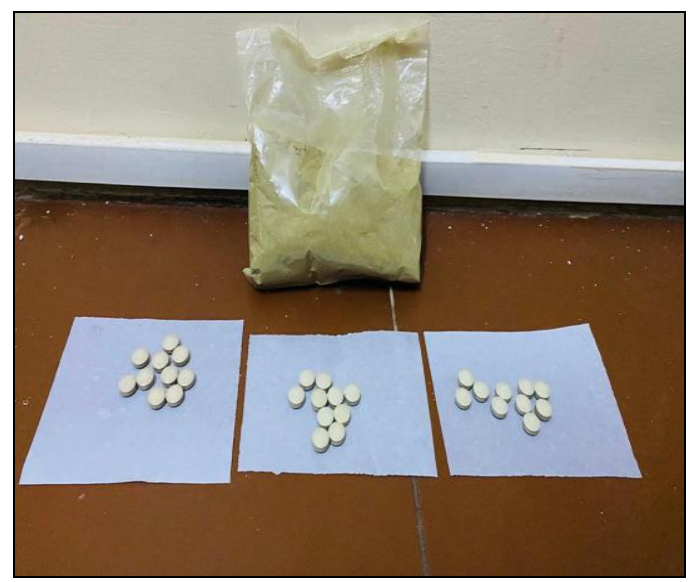

Fig. 1b: Broccoli powdered drug

\section{Determination of Vitamin C}

The redox titration method was used to determine vitamin $\mathrm{C}$ levels in the dried BOS vegetable $^{18}$. In a vegetable solution containing strong acid and potassium iodide, potassium iodate was added (KI). Molecular iodine is produced when potassium iodate reacts with potassium iodide. Iodine oxidizes vitamin $\mathrm{C}$, resulting in dehydroascorbic acid and iodide ion (I-). In a $250 \mathrm{ml}$ beaker, $25 \mathrm{ml}$ of Vitamin C standard solution, $5 \mathrm{ml}$ potassium iodide, $0.1 \mathrm{M}$ hydrochloric acid, and $1 \mathrm{ml}$ of the starch indicator solution were added. The potassium iodate solution was put into the burette and titrated against the beaker sample until a persistent blue-black color was observed. The 
method was repeated three times, yielding an average titer value for the sample. The amount of time spent steaming differed (i.e. $10 \& 20$ min. respectively) Using the formula, the percentage of ascorbic acid lost owing to steaming was computed.

$\%$ lost $=\mathrm{AAF}-\mathrm{AAH} / \mathrm{AAF} \times 100$

Where, $\mathrm{AAF}=$ the ascorbic acid content in the raw sample $\mathrm{AAH}=$ the ascorbic acid content of the steamed sample

\section{Antioxidant activity by DPPH assay}

When the DPPH free radical combines with hydrogen donors, it is converted to hydrazine. The DPPH radical is purple and turns yellow when it reacts with a hydrogen donor. It's a discoloration test that involves adding the antioxidant to a DPPH solution in ethanol or methanol and measuring the decrease in absorbance at $490 \mathrm{~nm}$. The experiment was conducted on a 96-well microtitre plate. In the wells of the microtitre plate, $10 \mu \mathrm{l}$ of each of the test samples or the reference solution were added separately to 200 $\mu l$ of DPPH solution. The test and standard solutions had final concentrations ranging from 1000 to $250 \mu \mathrm{l} / \mathrm{ml}$. The absorbance of each solution was measured at $517 \mathrm{~nm}$ with an ELISA reader against the appropriate test and standard blanks after a 20-minute incubation time at $37^{\circ} \mathrm{C}$, and the remaining DPPH was estimated $^{19}$.

\section{Determination of Physicochemical properties}

A standard method was used to analyze the powdered drug for physicochemical parameters. Chemical tests were performed to identify several phytoconstituents ${ }^{26}$.

\section{Estimation of calcium and oxalate}

Calcium was determined by titration against the sample solution with $0.01 \mathrm{M}$ EDTA as per the procedure given by AOAC/BIS/FSSAI ${ }^{21}$. The material is boiled in dilute sulphuric acid to remove the oxalate ions $(0.5 \mathrm{~N})$. Then, by titrating the extract with a standard $\mathrm{KMnO} 4$ solution, the oxalate content was calculated volumetrically. $1 \mathrm{~g}$ of material was weighed in an electronic weighing scale, then transferred to $30 \mathrm{ml}$ of $0.5 \mathrm{~N}$ sulphuric acid and placed in a water bath to heat for 15 minutes. To remove the oxalate ions, the material is cooked in dilute sulphuric acid $(0.5 \mathrm{~N})$. The oxalate content was then estimated volumetrically by titrating the extract with a standard potassium permanganate solution ${ }^{22}$.

\section{RESULTS AND DISCUSSION}

Minerals, vitamins, antioxidant polyphenols, and carotenoids that can scavenge free radicals, are abundant in green leafy vegetables ${ }^{23-25}$. The effect of steaming on antioxidant activity, the content of vitamin $\mathrm{C}$, calcium, and oxalate of Brassica oleracea sprout (BOS) was investigated in this study. BOS steam heating did not affect vitamin C levels. BOS didn't show any considerable loss in vitamin $\mathrm{C}$ and calcium, but oxalate was reduced to a great extent as a result of steaming. Vallejo et al. found a similar effect of twenty minutes of steaming on BOS vitamin $\mathrm{C}$ concentration ${ }^{26}$.

After 10 and 20 minutes of steaming, the steaming approach appeared to preserve vitamin $\mathrm{C}$ and calcium better, with a much smaller decline. The fresh weight after steaming was lower than the raw weight due to water loss in the vegetable tissue. The steaming method showed better results in preserving the nutrients of BOS and the desired pharmacological property can be expected. The results are shown in Table 1.

Table 1: Effect of Steaming on Vit. C, Calcium and Oxalate of BOS

\begin{tabular}{|c|c|c|c|c|c|}
\hline \hline S.No & Parameter & Standard value & Unsteamed & $\begin{array}{c}\text { Steamed (10 } \\
\text { min) }\end{array}$ & $\begin{array}{c}\text { Steamed (20 } \\
\text { min) }\end{array}$ \\
\hline 1 & Vitamin C & $89 \mathrm{mg}$ & $80 \mathrm{mg}$ & $78 \mathrm{mg}$ & $69 \mathrm{mg}$ \\
\hline 2 & Calcium & $47 \mathrm{mg}$ & $40 \mathrm{mg}$ & $38 \mathrm{mg}$ & $36 \mathrm{mg}$ \\
\hline 3 & Oxalate & $21 \mathrm{mg}$ & $23 \mathrm{mg}$ & $14 \mathrm{mg}$ & $11 \mathrm{mg}$ \\
\hline
\end{tabular}

Table 2: Effect of Steaming on antioxidant activity of BOS by DPPH method

\begin{tabular}{|c|c|c|c|c|}
\hline S.No & $\begin{array}{c}\text { Concentration } \\
(\mu \mathrm{g} / \mathrm{ml})\end{array}$ & $\begin{array}{c}\text { Unsteamed } \\
(\mathrm{I} \%)\end{array}$ & $\begin{array}{c}\text { Steamed (10 min) } \\
(\mathrm{I} \%)\end{array}$ & $\begin{array}{c}\text { Steamed (20 min) } \\
(\mathrm{I} \%)\end{array}$ \\
\hline 1 & 250 & 28.21 & 27.08 & 29.86 \\
\hline 2 & 500 & 47.66 & 48.98 & 49.71 \\
\hline 3 & 1000 & 68.50 & 72.12 & 73.34 \\
\hline
\end{tabular}


BOS that has been steam-cooked is shown to have a mild increase in antioxidant activity. Carotenoids which are powerful antioxidants and free radical scavengers that help to prevent coronary heart disease are more in BOS.

The scavenging activities are shown in Table 2. The table showed that the concentration of all the crude drugs was directly proportional to the $\%$ scavenging. All the goods have shown good antioxidant potential with better activity for BOS steamed for 20 minutes. The results show a good antioxidant potential in both steamed and unsteamed BOS indicating no considerable change as a result of steaming. When steamed BOS was compared to fresh BOS, the antioxidant activity increased.

The physicochemical properties such as total ash, water-soluble ash, acid insoluble ash, and sulfated ash, water-soluble extractive, and alcohol soluble extractives were performed for the steamed BOS. All the results comply with quality standards of Indian Medicinal plants (ICMR) and show considerable quality. Both the extracting solvents proved the efficiency in extracting the constituents. The results are shown in Table 3. The moisture content was well within the limits (less than 2\%). Phytochemical screening was carried out by standard methods. The results reveal that the crude drug showed carbohydrates, alkaloids, proteins, amino acids, phenolic compounds, tannins, and flavonoids in the steamed BOS powder. The results are shown in Table 4.

Table 3: Physicochemical properties of (BOS)

\begin{tabular}{|c|l|l||}
\hline S No. & \multicolumn{1}{|c|}{ Parameters } & \multicolumn{1}{|c||}{$\begin{array}{c}\text { Brassica } \\
\text { oleracea }(\text { BOS) }\end{array}$} \\
\hline \hline 1 & Total ash value & $4.50 \% \mathrm{w} / \mathrm{w}$ \\
\hline \hline 2 & Water soluble ash value & $3.00 \% \mathrm{w} / \mathrm{w}$ \\
\hline \hline 3 & $\begin{array}{l}\text { Acid insoluble ash } \\
\text { value }\end{array}$ & $1.90 \% \mathrm{w} / \mathrm{w}$ \\
\hline \hline 4 & Sulphated ash value & $1.25 \% \mathrm{w} / \mathrm{w}$ \\
\hline \hline 5 & $\begin{array}{l}\text { Alcohol soluble } \\
\text { extractive }\end{array}$ & $10.30 \% \mathrm{w} / \mathrm{w}$ \\
\hline \hline 6 & $\begin{array}{l}\text { Water-soluble } \\
\text { extractive }\end{array}$ & $8.00 \% \mathrm{w} / \mathrm{w}$ \\
\hline
\end{tabular}

Table 4: Phytochemical screening of (BOS)

\begin{tabular}{|c|l|c|}
\hline S No. & \multicolumn{1}{|c|}{ Name of the Test } & $\begin{array}{c}\text { Brassica } \\
\text { oleracea }\end{array}$ \\
\hline 1 & Alkaloids & $+\mathrm{ve}$ \\
\hline 2 & Carbohydrates & $+\mathrm{ve}$ \\
\hline 3 & Glycosides & $-\mathrm{ve}$ \\
\hline 4 & Saponins & $+\mathrm{ve}$ \\
\hline 5 & Proteins and Amino acids & $+\mathrm{ve}$ \\
\hline 6 & Phytosterols & -ve \\
\hline 7 & Fixed oils and fats. & -ve \\
\hline 8 & Phenolics \& Tannins & $+\mathrm{ve}$ \\
\hline 9 & Flavonoids & $+\mathrm{ve}$ \\
\hline 10 & Gum and Mucilage & -ve \\
\hline \hline
\end{tabular}

\section{Acknowledgment}

We are thankful to JSS College of Pharmacy, JSS Academy of Higher Education and Research (JSS AHER), Ooty, Nilgiris, Tamilnadu, India for the laboratory facilities.

\section{REFERENCES}

1. S. Kirti and K. Kanchan, "Broccoli sulforaphane: An insight into the analytical aspect and ultraviolet spectroscopic method development and validation", WJPPS, 4(10), 2234-2249 (2015).

2. B. Poljsak, V. Kovac and I. Milisav, "Antioxidants, Food Processing and Health", Anti Oxi, 10(3), 433, 1-12 (2021).

3. D. T. Verhoeven, R. A. Goldbohm, G. Van Poppel, H. Verhagen and P. A. Van Den Brandt, "Epidemiological studies on brassica vegetables and cancer risk", Cancer Epidemiol Biomarkers Prev, 5(9), 733-748 (1996).

4. P. Paśko, M. Tyszka-Czochara, A. Galanty, J. Gdula-Argasińska, P. Żmudzki, H. Bartoń, P. Zagrodzki, and S. Gorinstein, "Comparative Study of Predominant Phytochemical Compounds and Proapoptotic Potential of Broccoli Sprouts and Florets", Plant Foods Hum Nutr, 73(2), 95-100 (2018).

5. I. Herr and M.W. Büchler, "Dietary constituents of broccoli and other cruciferous vegetables: implications for prevention and therapy of cancer", Cancer Treat Rev, 36(5), 377-383 (2010). 
6. J. Moon, J.R. Kim, Y. Ahn and T. Shibamoto, "Analysis and antiHelicobacter activity of sulforaphane and related compounds present in broccoli (Brassica oleracea L.) sprouts", J Agric Food Chem, 58(11), 6672-6677 (2010).

7. P. C. Evans, "The influence of sulforaphane on vascular health and its relevance to nutritional approaches to prevent cardiovascular disease", EPMA J, 2(1), 9-14 (2011).

8. M. Akhlaghi and B. Bandy, "Dietary broccoli sprouts protect against myocardial oxidative damage and cell death during ischemia-reperfusion", Plant Foods Hum Nutr, 65(3), 193-199 (2010).

9. B. N. Enemchukwu, N. Uchenna, S. C. Udedi, K. I. Ubaoji and X. C. Akalonu, "Nutritional and Anti-nutritional Evaluation and Phytochemical Composition of Aqueous Leaf Extract of Mucuna pruriens", The Bio Sci Journ, 3(1), 93-100 (2015).

10. A. Popova and D. Mihaylova, "Antinutrients in Plant-based Foods: A Review", Open Biotechnol J, 13(1), 6876 (2019).

11. J. V. Higdon B. Delage, D. E. Williams and R. H. Dashwood, "Cruciferous vegetables and human cancer risk: Epidemiologic evidence and mechanistic basis", Pharmacol Res, 55, 224-236 (2007).

12. A. W. Munyaka, E. E. Makule, I. Oey, A. V. Loey and M. Hendrickx, "Thermal stability of L-ascorbic acid and ascorbic acid oxidase in broccoli (Brassica oleracea var. italica)", J Food Sci, 75(4), 336-340 (2010).

13. M. A. Masrizal, D. W. Giraud and J. A. Driskell, "Retention of vitamin C, iron, and beta-carotene in vegetables prepared using different cooking methods", J Food Qual, 20(5), 403-418 (1997).

14. E. Cieslik, T. Leszczynska, A. FilipiakFlorkiewicz, E Sikora and P. M. Pisulewski,"Effects of some technological processes on glucosinolate contents in cruciferous vegetables", Food Chem, 105(3), 976-981 (2007).

15. C. H. Lin and C. Y. Chang, "Textural change and antioxidant properties of broccoli under different cooking treatments", Food Chem, 90(1-2), 9-15 (2005).

16. E. Sikora, E. Cieslik E, T. Leszczynska, A. Filipiak-Florkiewicz, and P. M. Pisulewski, "The antioxidant activity of selected cruciferous vegetables subjected to aqua thermal processing", Food Chem, 107(1), 55-59 (2008).

17. F. Vallejo, F. Tomas-Barberan and C. Garcia-Viguera, "Glucosinolates and vitamin $\mathrm{C}$ content in edible parts of broccoli florets after domestic cooking", Eur Food Res Technol, 215(4), 310-316 (2002).

18. AOAC (Association of Official Analytical Chemists) Official Methods of Analysis. Washington DC: AOAC International; Official Method 985.33. Vitamin C (Reduced Ascorbic Acid) in Ready-to-feed Milk-based Infant Formula 2,6-Dichloroindophenol Titrimetric Method, 1990, 1108-1109.

19. R. K. Singla, N. Jaiswal, V. B. Giliyaru and H. Jagani, "Antioxidant and antimicrobial activities of Cocos nucifera Linn. (Arecaceae) endocarp extracts", Indo glob J pharm sci, 1(4), 354-367 (2011).

20. C. K. Kokate, A. P. Purohit, S. B. Gokhale, "Textbook of Pharmacognosy. 39th ed.," Nirali Prakashnan Pune, 2001, 609-611.

21. AOAC International. Guidelines for dietary supplements and botanicals (AOAC Official Method of Analysis, Appendix K). AOAC International, Rockville, 2013, 1-32.

22. AOAC International. Guidelines for dietary supplements and botanicals (AOAC Official Method of Analysis, Appendix K). AOAC International, Rockville, 2013, 40 -45.

23. G. Oboh, "Effect of blanching on the antioxidant properties of some tropical green leafy vegetables", $\boldsymbol{L W T}$ Food $\mathbf{S c i}$ Technol, 38(5), 513-517 (2005).

24. K. D. P. P. Gunathilake, K. K. D. S. Ranaweera and H. P. V. Rupasinghe, "Change of phenolics, carotenoids, and antioxidant capacity following simulated gastrointestinal digestion and dialysis of selected edible green leaves", Food Chem, 245, 371-379 (2018). 
25. N. Andarwulan, D. Kurniasih, R. A. Apriady, H. Rahmat, A. V. Roto and B. W. Bolling, "Polyphenols, carotenoids, and ascorbic acid in underutilized medicinal vegetables", J Funct Foods, 4(1), 339-347 (2012).
26. F Vallejo, F. Tomas-Barberan and C. Garcia-Viguera, "Glucosinolates and vitamin C content in edible parts of broccoli florets after domestic cooking", Eur Food Res Technol, 215(4), 310-316 (2002). 


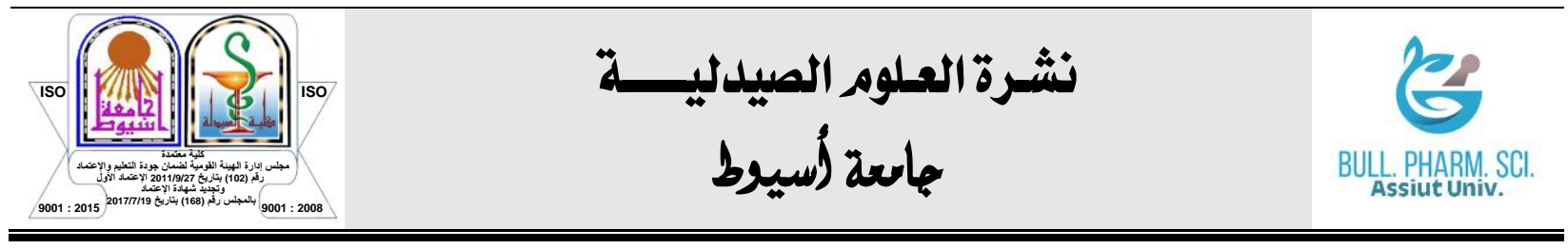

تأثير التبخير على مضادات الأكسدة في براعم براسيكا أولير اسيا ، محصول بارد

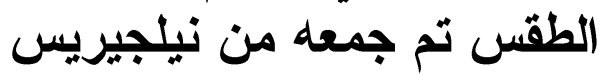

\section{رامو جوفيندان}

قسم العقاقير ، ج س س كلية الصيدلة ، ج س س أكاديمية التعليم العالي والبحث، أوتي ، نيلجيريس ، تاميل نادو ، الهند

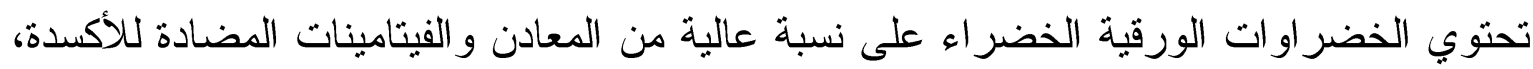

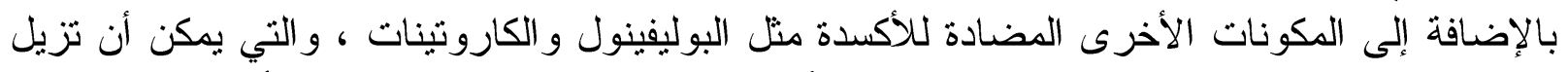

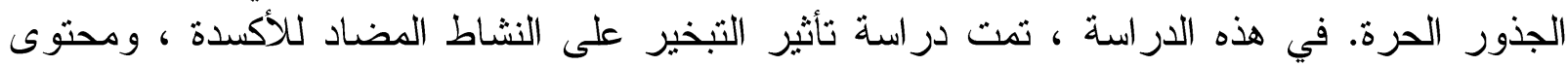

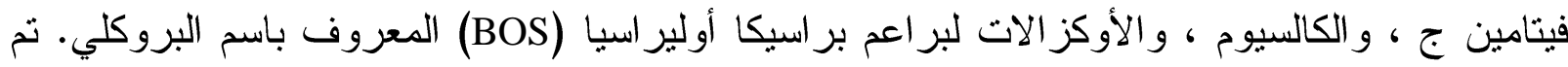

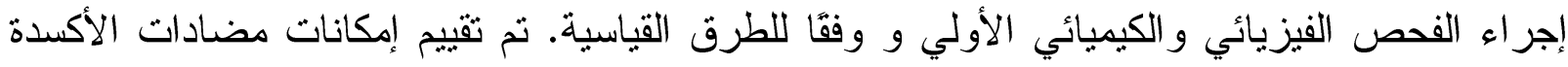

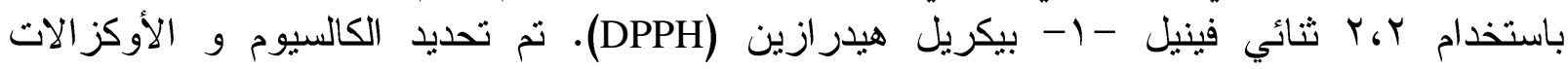

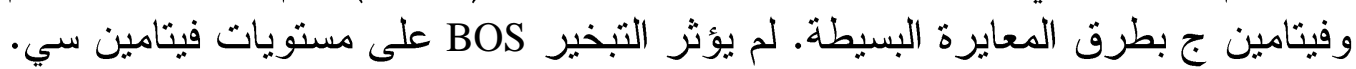

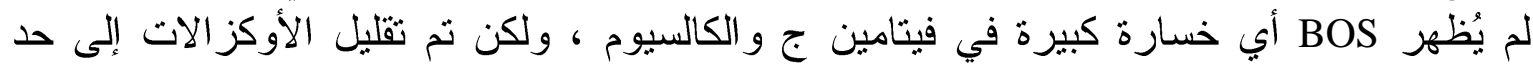

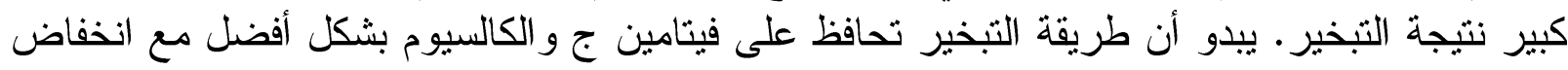

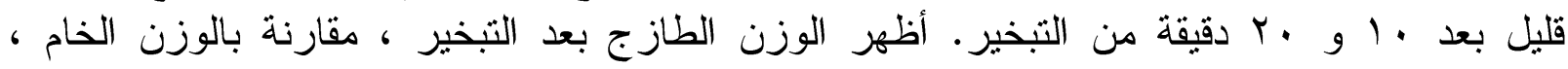

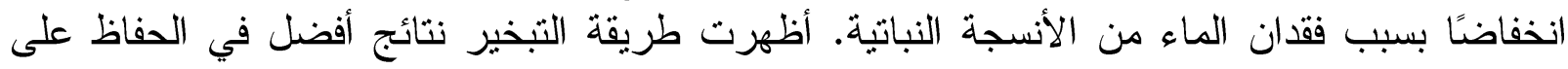
العناصر الغذائية لــ BOS وبالتالي الخاصية العلاجية المطلوبة. 